\title{
On gonadic maturation and reproductive strategy in deep-sea benthic octopus Graneledone macrotyla
}

\author{
Ángel Guerra • María Pilar Sieiro • Álvaro Roura • \\ Julio M. Portela $\cdot$ José Luís del Río
}

Received: 21 February 2012/Revised: 20 November 2012/Accepted: 21 November 2012/Published online: 1 December 2012

(C) Springer-Verlag Berlin Heidelberg and AWI 2012

\begin{abstract}
The new information reported in this paper is based on five maturing and mature females of the largetuberculate octopus Graneledone macrotyla. These specimens were caught in bottom trawl surveys ATLANTIS 2009 (February 24 to April 1, 2009) and ATLANTIS 2010 (March 9 to April 5, 2010) carried out off the Argentinean Economic Exclusive Zone. Capture depth ranged from 475 to $921 \mathrm{~m}$ and sea bottom temperature between 2.8 and $3.1{ }^{\circ} \mathrm{C}$. Development of the complex ovary, oviducts, and oviducal glands during gonadic maturation is described. The absence of spermathecae in the oviducal glands and the presence of fertilized eggs inside the ovary suggested that fertilization took place within the ovary. Histological techniques showed the presence of four types of oocytes. Maturing oocyte size-frequency distribution was polymodal. Fluorescence reaction showed that atresia occurred in both early and later oocyte maturation stages. Atresia affected $48-55 \%$ of the initial number of oocytes. The maximum observed potential fecundity was estimated at 250-300 eggs. G. macrotyla showed a group-synchronous ovulation pattern, regulative atresia, and a batching
\end{abstract}

Communicated by H.-D. Franke.

Á. Guerra $(\bowtie)$ · Á. Roura

Instituto de Investigaciones Marinas (CSIC),

Eduardo Cabello 6, 36208 Vigo, Spain

e-mail: angelguerra@iim.csic.es

M. P. Sieiro

Centro Tecnológico del Mar-Fundación CETMAR,

Eduardo Cabello s/n, 36208 Vigo, Spain

J. M. Portela · J. L. del Río

Instituto Español de Oceanografía (IEO) C. O. de Vigo,

P. O. Box 1552, 36200 Vigo, Spain spawning pattern with a few egg batches spawned intermittently over an extended period of spawning.

Keywords Reproduction - Atresia - Deep-sea octopods · Graneledone macrotyla · Patagonian slope · Southeast Atlantic

\section{Introduction}

Cold-water deep-sea octopods, both in Arctic and Antarctic waters, have large eggs (15-35 mm length) and low fecundity, ranging from a dozen to a few hundred oocytes, and hatchlings which are among the largest and most advanced known (Kuehl 1988; Laptikhovsky 1999, 2001; Laptikhovsky et al. 2007; Voight and Drazen 2004).

Bello (2006) suggested that the large-egged Graneledone pacific is a "multiple spawner," based on the simultaneous occurrence of oocyte cohorts at different oogenic stages in five females collected in the north-east Pacific Ocean, as deep as $2765 \mathrm{~m}$. This reproductive strategy requires a group-synchronous ovulation and somatic growth between separate spawning events (Rocha et al. 2001). Nevertheless, the scattered information available on the reproduction of deep-sea octopods suggests that oocyte growth and maturation seem to be synchronous, although in maturing females, the oocyte size distribution appears to be bimodal or, rarely, polymodal (Kuehl 1988; Laptikhovsky 1999, 2001; Barrat et al. 2008). The existence of synchronous or group-synchronous ovulation in these species is, therefore, controversial.

Observations recorded from ROVs (Drazen et al. 2003) and submersibles (Voight and Grehan 2000) have shown that these deep-sea octopods attach their eggs in shelters on rocky ground, on outcrops and ledges, and that females 
brood their egg mass. Whether a brooded egg mass is spawned simultaneously or in several successive batches during an extended spawning period is also a matter of discussion. Laptikhovsky (pers. comm.) suggested that this question can only be solved by studying postovulatory follicles (POFs), which provide information on how many eggs and batches were actually laid. At present, however, only few specimens in such a reproductive stage have been studied extensively.

Another question relates on whether females continue to grow between the successive release of egg batches, as seems to occur in many cirrate and some incirrate octopods considered as "continuous spawners" (Rocha et al. 2001).

On the Patagonian slope (475-921 m), the large-tuberculate octopus Graneledone macrotyla Voss, 1976 inhabits shallower waters than in the sub-Antarctic area $(1,647-2,044 \mathrm{~m})$. The species inhabits the plume of cold sub-Antarctic waters, which is pushed far north into the southwestern Atlantic by the Falkland-Malvinas Current (Guerra et al. 2012). These authors described, for the first time, the female genitalia of $G$. macrotyla. Owing to the presence of a bimodal size distribution of oocytes, a reproductive strategy with multiple spawning was suggested. Besides, the presence of shrivelled oocytes within the ovary was considered as a symptom of atresia. Cases of atresia, or degeneration of some oocytes as a result of intragonad competition for nutrient supply, have been reported in Eledone cirrhosa (Boyle and Chevis 1991), the squids Loligo vulgaris reynaudii and Dorytheuthis gahi (Sauer et al. 1993; Melo and Sauer 1998; Laptikhovsky and Arkipkin 2001), and large-egged deep-sea squids (Laptikhovsky et al. 2007). Although recent observations have shown that massive atresia is relatively common in fish (Rideout and Tomkiewicz 2011), and cases of massive atresia have been recorded in deep-sea octopods (Kuehl 1988; Laptikhovsky 1999), the later has not received special attention to date. Accordingly, the aim of this paper is to study atresia in females of $G$. macrotyla during gonadic maturation and how it affects the poorly known reproductive strategy of this species.

\section{Materials and methods}

Eleven specimens of G. macrotyla (Table 1) were caught in two multidisciplinary research cruises conducted by the Instituto Español de Oceanografía (IEO) to assess the biomass of the main commercial fish stocks in the High Seas of the Southwest Atlantic by using the swept area method through a bottom trawl Lofoten type gear (Portela et al. 2010). The surveys ATLANTIS 2009 and 2010 were carried out between February 24 and April 1, 2009 (Guerra et al. 2011) and from March 9 to April 5, 2010, respectively, on board the R/V Miguel Oliver. Depth of captures ranged from 475 to $921 \mathrm{~m}$. Sea bottom temperature varied from 2.8 to $3.1^{\circ} \mathrm{C}$.

On board, catches were sorted immediately after capture. Cephalopods were stored in labelled plastic bags and frozen at $-20{ }^{\circ} \mathrm{C}$ on board. Specimens were subsequently transported to the Instituto de Investigaciones Marinas (IIM, CSIC) in Vigo, Spain, for detailed examination.

After thawing at room temperature, the specimens were identified and sexed. Five females were identified and preserved in ethanol $70 \%$. All measurements and histological sections were taken on preserved specimens. All specimens were stored in the collection of the MDMG: Museo do Mar de Galicia (Vigo, Spain).

Two indices were calculated: the proximal oviduct length index (POLI: proximal oviduct length/dorsal mantle length $100 \times$ ), and the distal oviduct length index (DOLI: distal oviduct length/dorsal mantle length $100 \times$ ).

The histological study of the oviducal gland and oviducts was carried out on three specimens MDMG552011, MDMG68A2011, and MDMG68B2011 (Table 2), whose glands had a maximum diameter of 12.1, 16.0, and $27.0 \mathrm{~mm}$, respectively.

Table 1 Reproductive traits of G. macrotyla females

\begin{tabular}{|c|c|c|c|c|c|c|c|c|c|c|c|c|}
\hline \multirow[t]{2}{*}{ Sp. No. } & \multirow[t]{2}{*}{ ML (mm) } & \multirow[t]{2}{*}{ TW (g) } & \multirow[t]{2}{*}{ Mat } & \multicolumn{6}{|c|}{ Type of oocytes and eggs } & \multirow[t]{2}{*}{ OGD $(\mathrm{mm})$} & \multirow[t]{2}{*}{ POLI } & \multirow[t]{2}{*}{ DOLI } \\
\hline & & & & $\mathrm{S} 1$ & $\mathrm{~S} 2$ & S3 & $\mathrm{S} 4$ & S5 & Total & & & \\
\hline MDMG552011 & 78.0 & 318 & $\mathrm{Sm}$ & 230 & 2 & & & & 232 & 12.1 & 6.4 & 61.0 \\
\hline MDMG68C2011 & 80.0 & 666 & $\mathrm{Sm}$ & 258 & 9 & & & & 267 & 9.2 & 7.5 & 69.3 \\
\hline MDMG472011 & 107.0 & 760 & M & - & - & 3 & 103 & 3 & 109 & 19.0 & 8.7 & 50.0 \\
\hline MDMG68A2011 & 98.2 & 1,064 & M & - & - & 4 & 95 & 1 & 100 & 16.0 & 9.1 & 52.0 \\
\hline MDMG68B2011 & 110.0 & 1,076 & M & - & - & 108 & - & & 108 & 27.0 & 9.0 & 53.3 \\
\hline
\end{tabular}

Sp No Specimen catalogue number, $M D M G$ Museo do Mar de Galicia, Vigo, Spain; $M L$ mantle length, $T W$ total weight, $M a t$ maturity stage (Sm maturing, $M$ mature), $O G D$ oviducal gland diameter, $P O L I$ proximal length oviduct index, DOLI distal length oviduct index. For S1-S5 see explanation in Table 2 
Table 2 Graneledone macrotyla oocyte and egg characteristics

\begin{tabular}{llllll}
\hline Type of oocytes/eggs & S1 & S2 & S3 & S4 & S5 \\
\hline Length $(\mathrm{mm})$ & $1.0-3.0$ & $3.1-9.0$ & $18.8-25.5$ & $12.8-17.2$ & $18.8-20.5$ \\
Width (mm) & - & $5.4-1.0$ & $11.7-9.5$ & $4.3-3.0$ & $12.2-11.4$ \\
OW \pm SD (mg) & - & - & $733.86 \pm 71.84(n: 7)$ & $355.67 \pm 120.5(n: 7)$ & $1,399 \pm 139.31(n: 7)$ \\
Outer case & Rigid, opaque & Rigid, opaque & Rigid, translucent & Rigid, translucent & Hard, opaque \\
Longitudinal striae & No & No & Yes & Yes & No. Smooth surface \\
Attached in bunch & Yes & Yes & Yes & Yes & No. Free within ovary \\
Distal micropyle & Yes, narrow & Yes, narrow & Yes, narrow & Outer case widely open & No \\
Peduncle & Long & Long & Long, 17-19 mm & Long & Short, 4-5 mm \\
Fertilized & No & No & No & No & Yes \\
Observations & Swollen AO & Swollen & Swollen & Flabby, empty AO & Hen's egg shape. Color: beige \\
\hline
\end{tabular}

$O W$ oocyte weight in $\mathrm{mg}, A O$ atretic oocytes

Histological studies of oocytes in different stages of development were carried out on the specimens MDMG552011, MDMG68A2011, MDMG68B2011, and MDMG472011, which represent the four maturation stages observed (Table 2). Oocytes were fixed with a solution of $10 \%$ buffered formaldehyde in a ratio volume formaldehyde/tissue approximately equal to 50 . After fixative action, profuse cleaning with water was done. Then, each sample was dehydrated in ethylic alcohol in increasing concentrations from 70 to $100 \%$ and embedded individually in paraffin blocks $\left(58^{\circ} \mathrm{C}\right)$ according to standard histological techniques (Gabe 1968). Longitudinal sections at different levels were produced (6-8 $\mu \mathrm{m}$ thick) and stained with Harry's hematoxylin-eosin. In order to distinguish between postovulatory follicles (POFs) and atretic oocytes (AO), oocyte preparations were evaluated using a fluorescence microscope with a B-2A filter set with a $450-490 \mathrm{~nm}$ excitation filter, a 505-nm dichroic mirror and a 520-nm barrier filter (Saborido-Rey et al. 2007). Observations were carried out, and photographs taken, with a binocular $(63 \times$ magnification) and a light microscope (100-1,000 $\times$ magnification) coupled with a Nikon DXM 1200F digital video camera. The software used was NIS-Elements D 3.00 SP6 (Build 539) (@ 1991-2008 Nikon Laboratory Imaging).

\section{Results}

Reproductive system maturation

Measurements of reproductive traits of maturing and mature female G. macrotyla (Fig. 1a) are shown in Table 1. In the mid-portion of each oviduct, there is an oviducal gland, which changes in size and color from white-beige (Table 1; Fig. 1b) to blue-blackish during the maturation process (Table 1; Fig. 1c, d). The proximal oviducts are short (POLI 6.4-9.1) and wide. The distal oviducts are long (DOLI 50.0-69.3) and wider in the proximal than in the distal part. Their walls and shape experience changes during growth and maturation. While being thin in maturing females, with the apex practically closed and adopting a hook-like structure, the walls in mature females are thick and completely open (Fig. 1b, c). Conversely, the maturation process involves lengthening of oviducts and widening of oviducal glands. The ovary is almost spherical and does not experience any substantial changes during growth and maturation, except an increase in volume from $8.2 \mathrm{~cm}^{3}$ (ovary: $2.5 \mathrm{~cm}$ diameter in maturing female MDMG552011) to $143.7 \mathrm{~cm}^{3}$ (ovary: $6.5 \mathrm{~cm}$ diameter in mature female MDMG68A2011).

The oviducal gland is structurally formed by one huge concentric peripheral gland around the oviduct, separated by a thin sheet of connective tissue (Fig. 2a). The peripheral gland is formed by groups of concentric cells with basal nuclei and a central lumen; in females close to maturity, their cytoplasm is densely packed with eosin granulations (Fig. 2b). Spermathecae were absent. No spermatangia or free sperm were observed within the ovaries or attached to the egg filaments.

\section{Oocytes}

Four types of oocytes (S1-S4) and fertilized eggs (S5) were observed inside the ovaries. Their characteristics are shown in Table 2 and Figs. 3, 4, 5, 6, 7. During oogenesis, in addition to a progressive increase of oocytes in size, the outer case of oocytes transforms from rigid and opaque in the earlier stages (S1 and S2, Fig. 3a-c) to translucent and with longitudinal striae in the more advanced stages of maturation (S3, Fig. 3d). During these stages (S1-S4), all oocytes were attached to the ovary by long peduncles forming a bunch (Fig. 3b). Oocytes at stages S1 and S2 showed no longitudinal striae and had yellow-brown spots on the surface (Fig. 3b). A very narrow micropyle was 

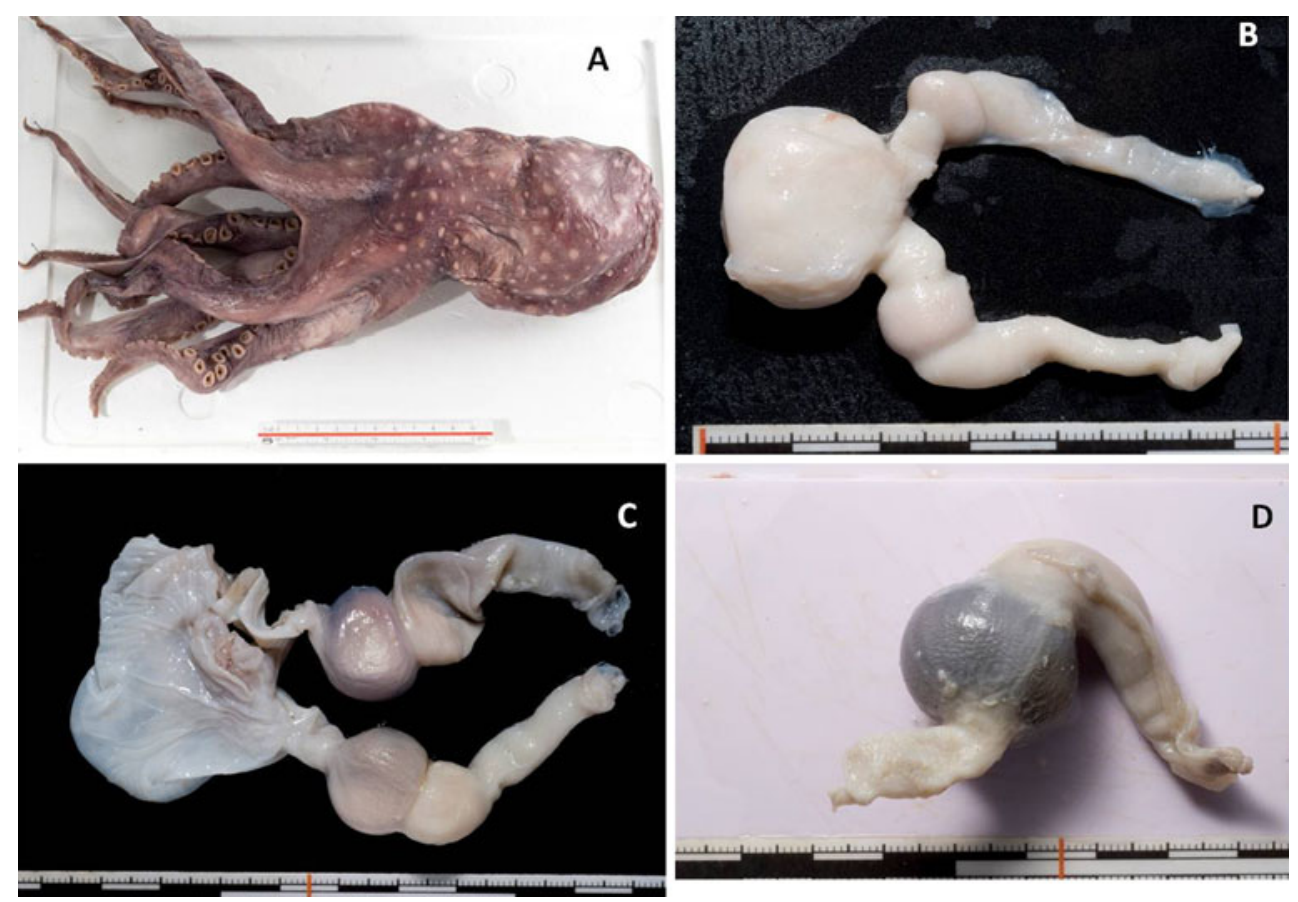

Fig. 1 Graneledone macrotyla. a Dorsal view of the specimen MDMG68B2011; b reproductive system of the maturing female MDMG552011; c reproductive system of the mature female MDMG472011; d detail of the oviducal gland of specimen MDMG68B2011

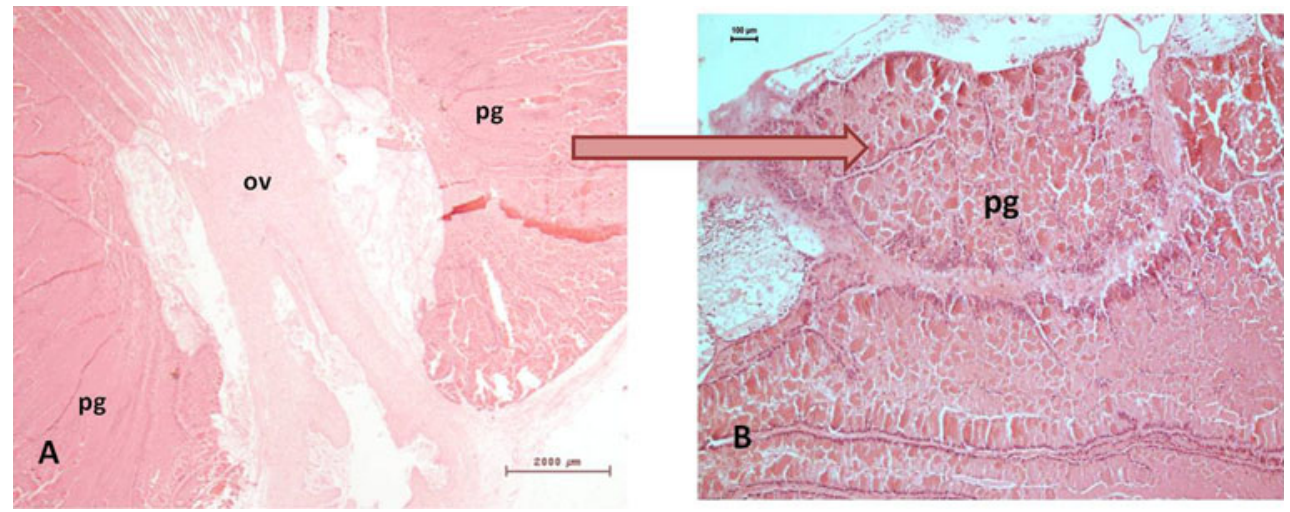

Fig. 2 Graneledone macrotyla. Oviducal gland of mature females MDMG68A2011 and MDMG68B2011. a Longitudinal section in the middle portion stained with hematoxylin-eosine (h-e); ov oviduct, $p g$ peripheral gland, b detail of the $p g$ showing eosinophil granulations

present at the distal pole of all oocytes of stages S1-S3 (Fig. 3e).

In the maturing female MDMG552011, 90.5 and $9.5 \%$ of the oocytes present within the ovary were in stages $\mathrm{S} 1$ and $\mathrm{S} 2$, respectively. In the other maturing female (MDMG68C2011), the values amounted to 92.9 and $7.1 \%$, respectively (Table 1). The total number of oocytes in these cases did not exceed 267, which suggests that the potential fecundity (PF) of G. macrotyla is low (approximately between 250 and 300 oocytes). Moreover, the presence of oocytes differing in size and stage of maturation indicates that oogenesis of this species is group-synchronous.
All oocytes (108) found within the ovary of the mature female MDMG68B2011 were in stage S3 (Figs. 3d, 4a, b; Table 1). No POFs were found in the histological sections examined.

An oocyte in stage $\mathrm{S} 4$ is shown is Fig. 4c. Its outer case was rigid and showed longitudinal striae. All oocytes at that stage showed long peduncles and were attached to the ovary forming a bunch (Fig. 4a). Their most conspicuous characteristics were an outer case, widely open in the distal zone, with a flaccid consistency. Mature females MDMG472011 and MDMG68A2011 showed 94.5 and $95 \%$ of their oocytes in this stage. 

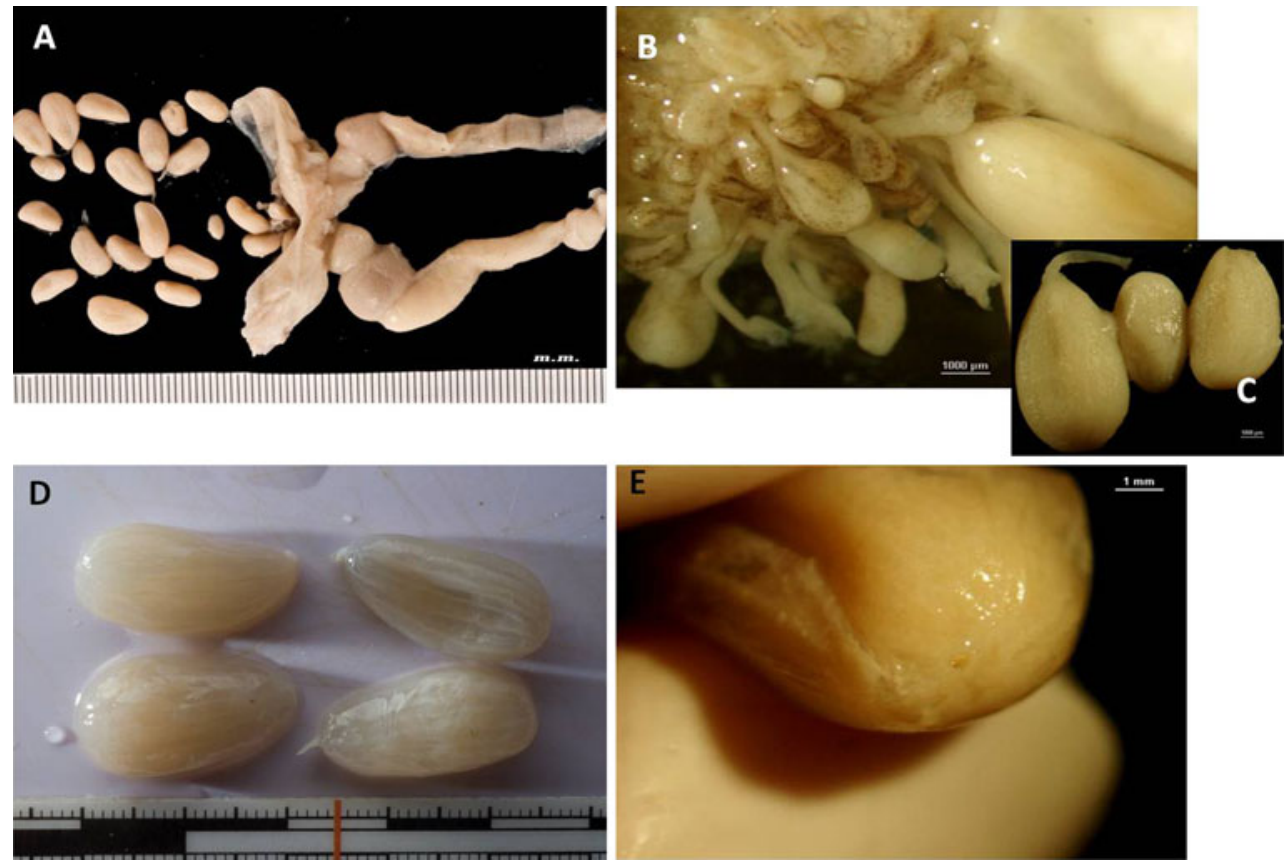

Fig. 3 Graneledone macrotyla. a Oocytes in stage $\mathrm{S} 2$ from maturing female MDMG552011 (see Table 2 for details); b oocytes S1 and S2 within the ovary forming a bunch; c, details of oocytes S1 and S2;

d Oocytes S3 from mature female MDMG68B2011 showing longitudinal striae; e micropyle was present in S1-S3 oocytes
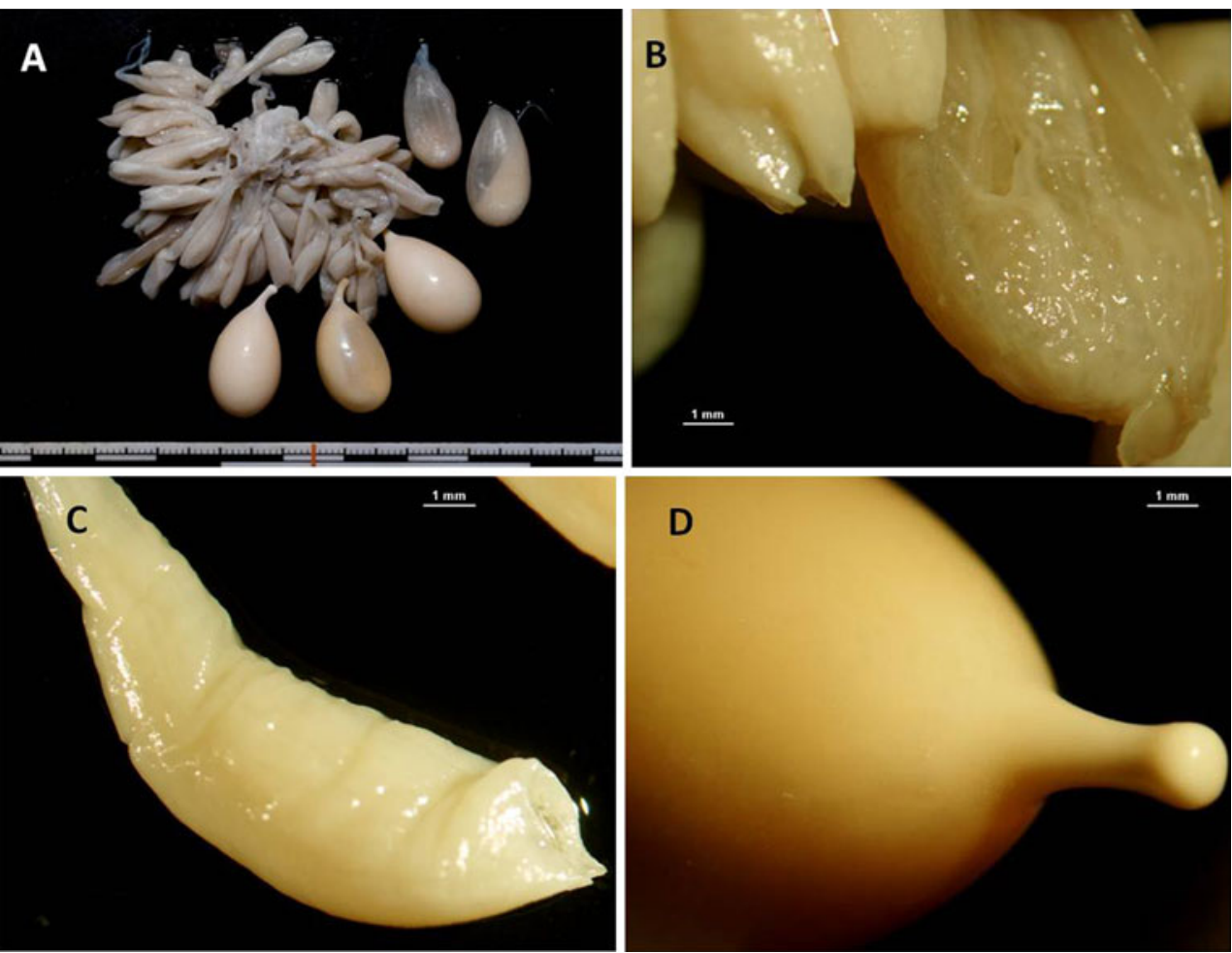

D

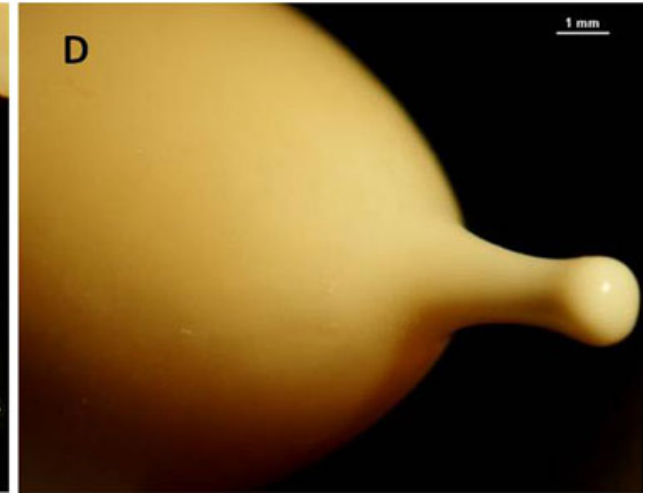

Fig. 4 Graneledone macrotyla. Mature female MDMG472011. a Oocytes and fertilized eggs within the ovary; b detail of oocytes S3 and S4; b oocyte S4; d fertilized egg

Within the ovaries of the mature females MDMG472011 and MDMG68B2011, three and one fertilized eggs (S5) were found, respectively (Table 1; Fig. 4a, d). These eggs were free within the ovary and oval in form. Their external capsule was hardened, lacking longitudinal striae, and beige in color. The micropyle had disappeared and their peduncles 


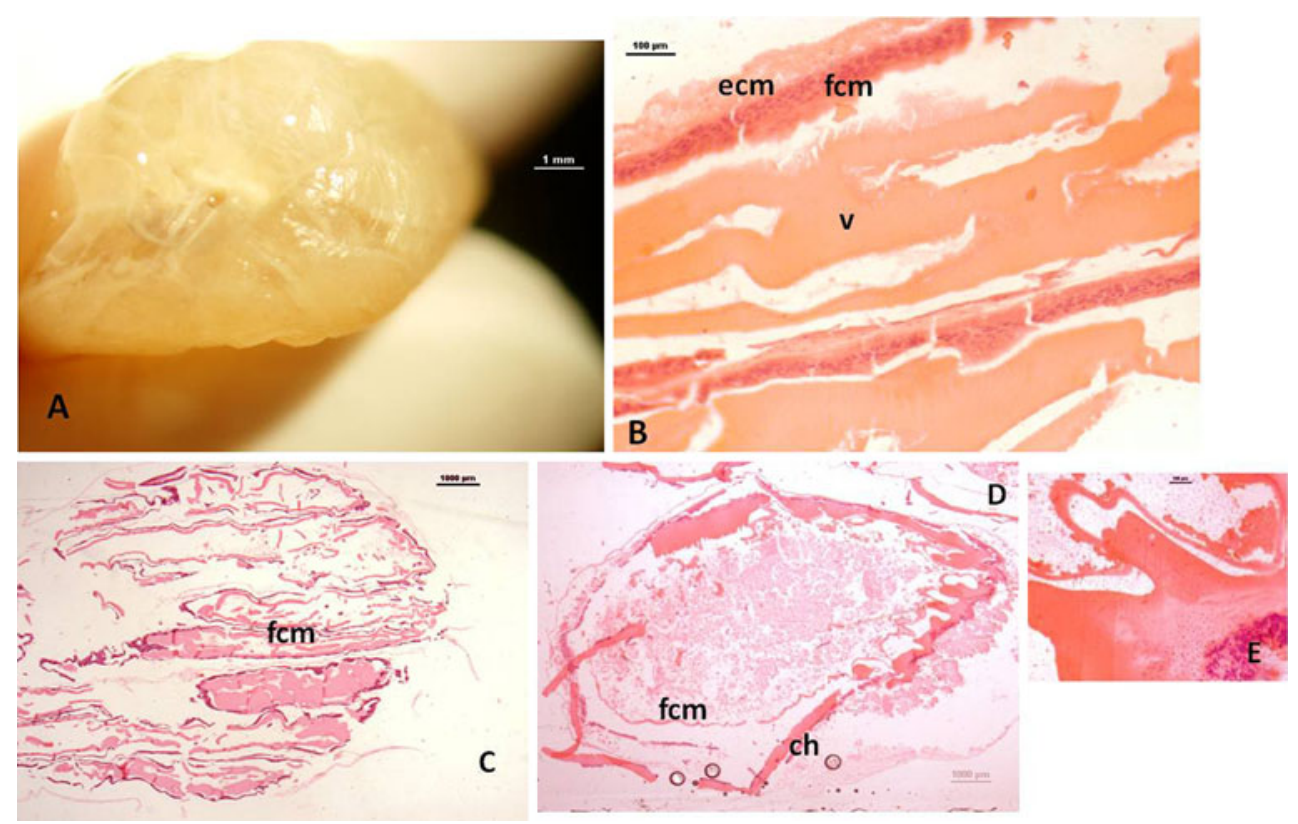

Fig. 5 Graneledone macrotyla. Mature female No MDMG68B2011. a External aspect of an oocyte type S3 showing longitudinal striae and micropyle; b longitudinal section of that oocyte, Ecm epithelial cell membrane, $f m c$ follicular cell membrane, $v$ vitellus, c oocyte $\mathrm{S} 3$; d, longitudinal section of oocyte S3 showing $f m c$ and chorion $(c h)$; e detail of the chorion
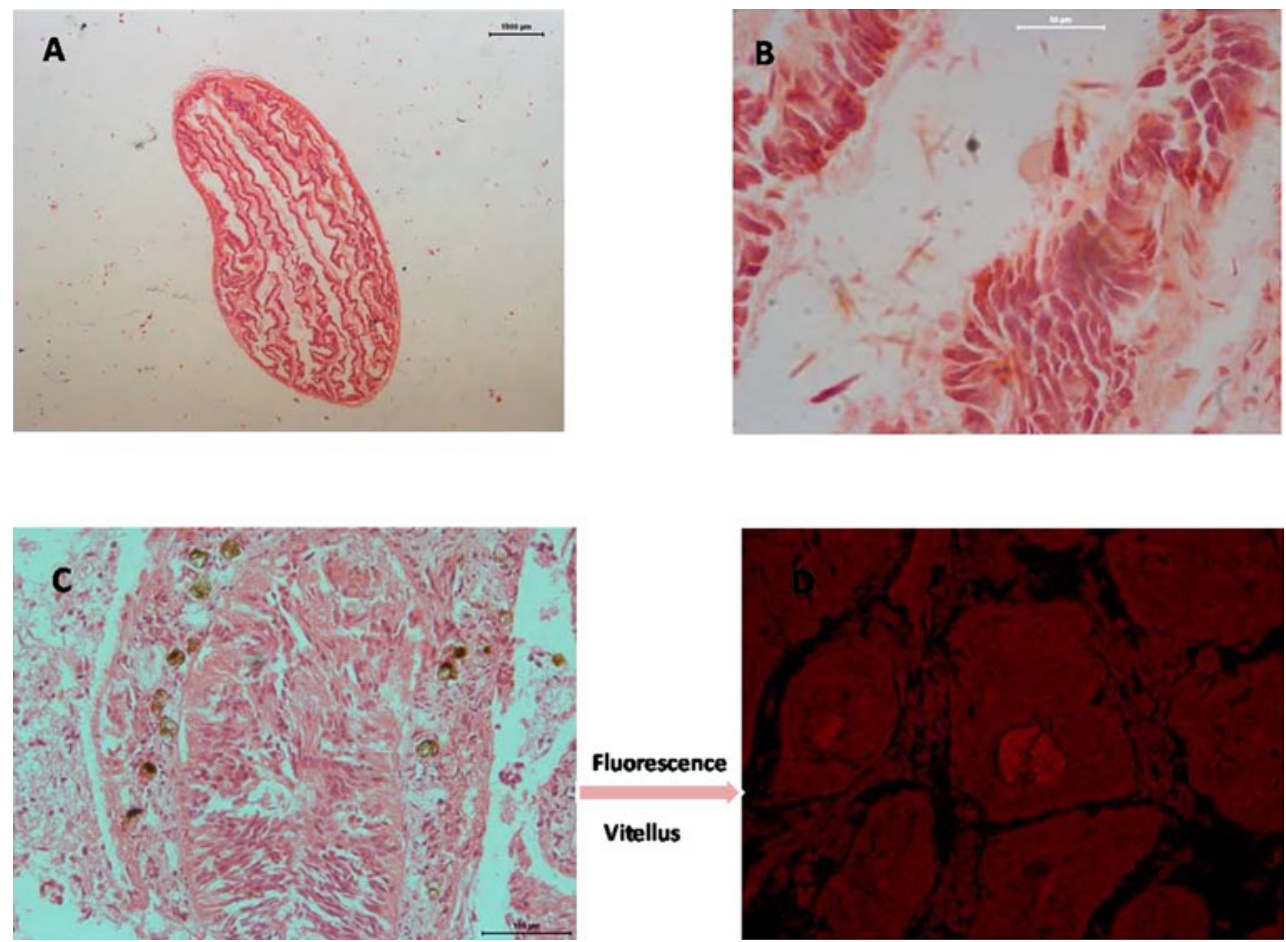

Fig. 6 Graneledone macrotyla. Maturing female MDMG552011. a Longitudinal section of an oocyte in stage S1 stained with h-e; b detail of the follicular cells of that oocyte; $\mathbf{c}$ longitudinal section of another oocyte S1 stained with $\mathrm{h}-\mathrm{e}$; d vitellus, atresia

considerably shortened (Table 2; Fig. 4d). No POFs were found in these females.

Figure 5 illustrates the external aspect of an oocyte of the mature female MDMG68B2011 in stage S3 showing longitudinal striae and a micropyle (Fig. 5a). A longitudinal section of that oocyte stained with h-e (Fig. 5b) indicated the existence of a typical epithelial cell membrane, a follicular cell membrane, a vitellus at an 


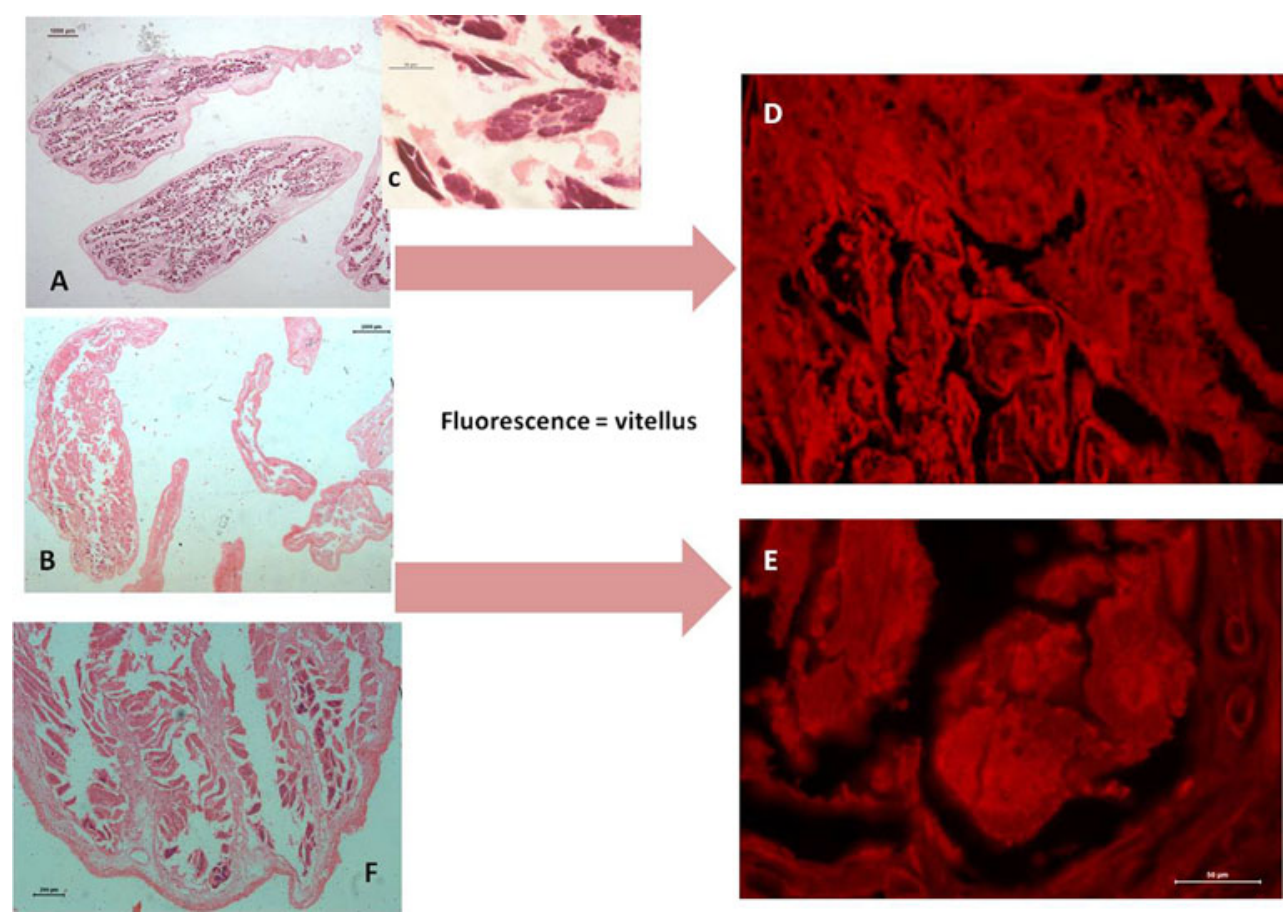

Fig. 7 Graneledone macrotyla. a Longitudinal section of an oocyte type S4 stained with h-e from mature female MDMG472011; b longitudinal section of an oocyte type S4 stained with h-e from mature female MDMG68A2011; $\mathbf{c}$ detail of granulated cells; $\mathbf{d}$, e, and

advanced stage of maturation, and chorion already formed (Fig. 5c-e).

Size and depth of the longitudinal striae suggest that S4 oocytes are at a more advanced stage than S2 oocytes, but at a less advanced stage than S3 oocytes.

\section{Atresia}

Histological images of an oocyte in stage S1 show jumbled structures and a swelled connective tissue, while follicular cells are difficult to detect (Fig. 6a-d). Fluorescence reaction revealed that vitellus was present at this stage, which indicated that these were actually oocytes and not POFs. Therefore, these oocytes were considered atretics (AO). Initial oocytes manifesting signs of degeneration represented high rates (48-55\%) of oocytes present inside the ovaries of the maturing females MDMG552011 and MDM68C2011. On the other hand, oocytes S2 showed follicular cells arranged in longitudinal stripes and an organization of maturing cells with follicular folding.

Figure 7 shows a longitudinal section of type S4 oocyte from the mature females MDMG472011 and MDMG68A2011 stained with h-e. Taking into account that these oocytes lost their form (Fig. 7a, b), that the fluorescence reaction was positive, showing the presence of vitellus (Fig. 7d, e), and that their follicular cells were located around and overlapping the ooplasma (Fig. 7f), f fluorescence reaction of oocytes from MDMG472011 and MDMG68A2011, vitellus present, follicular cell membrane $(f \mathrm{~cm})$ in regression, atresia

these oocytes should also be considered as atretics (AO) and not as POFs.

Therefore, as suggested by the presence of AO in stages S1 and S4, oocyte degeneration may occur in both early and late stages of maturation.

\section{Discussion}

Maturation of the reproductive system and oocyte fertilization

The ovary, oviducts, and oviducal glands complex of G. macrotyla is similar to that described by Bello (2006) for G. pacifica, although the swelling of the distal oviduct just behind the oviducal glands present in $G$. pacifica (Bello 2006) was not observed in G. macrotyla. However, it should be considered that some deformations may have occurred in the preserved specimens (Voight 2001). The proximal oviduct of $G$. pacifica is slightly longer than in G. macrotyla. The POLI estimated from Bello (2006), excluding the probably erroneous measurement of $23 \mathrm{~mm}$, ranged from 7.0 to 11.3 , whereas in G. macrotyla that index ranged from 6.4 to 9.1. However, the contrary applies to the distal oviduct, with a DOLI ranging from 17.3 to 26.0 in G. pacifica (Bello 2006), and from 52.0 to 69.3 in G. macrotyla (Table 1). 
As in G. pacifica (Bello 2006), the overall maturation process in G. macrotyla involves lengthening of oviducts and widening of oviducal glands. There is no possible comparison between the changes in color observed in the oviducal glands of macrotyla during the maturation process and those of pacificus, because Bello (2006) did not indicate anything in this regard.

It remains uncertain whether fertilization in G. macrotyla takes place inside the ovary, as observed in two species of the Eledoninae (Perez et al. 1990), or whether the oocytes pass along the oviducts, as in Octopodinae and Bathypolypodinae (Mangold 1989. Nonetheless, the absence of spermathecae in the oviducal glands and the presence of fertilized eggs inside the ovary of G. macrotyla suggest that fertilization takes place within the ovary. On the other hand, considering the relationship between sperm morphology and the mode of fertilization (Franzén 1955; Healy 1988), the type of spermatozoid found in the Graneledoninae (Roura et al. 2009) suggests a mode of fertilization in this subfamily which is more similar to that in the Octopodinae (Longo and Anderson, 1970) and the Bathypolypodinae (Roura et al. 2010) than to that displayed by the Eledoninae (Selmi 1996).

Oocytes, reproductive strategy, and fecundity

All oocytes (108) within the ovary of the mature female MDMG68B2011 were in an advanced stage (S3). There were no oocytes left in earlier stages of maturation (Table 1), and no POFs were found in the histological sections examined. Such a scenario has never been observed in any deep-sea octopus before. Two alternative interpretations are possible: (1) Synchronous maturation of oocytes which are spawned in one or several batches. This assumption is consistent with the oocyte size frequency in the female MDMG472011, but it is inconsistent with the scenario shown by the maturing females MDMG552011 and MDMG68C2011. (2) Group-synchronous production of oocytes, many of which are reabsorbed (as observed) while the others undergo maturation and are eventually spawned in a single or several batches. Atresia of very early oocytes is called "regulative atresia" and seems to be relatively frequent in other species (Laptikhovsky et al. 2007). This second interpretation neither contradicts the scenario shown by the mature females MDMG472011 and MDMG68A2011 nor that of the maturing females MDMG552011 and MDMG68C2011, and this could also be the case with G. pacifica, since Bello's (1990) conclusions were based on subadult specimens.

Consequently, G. macrotyla seems to have a groupsynchronous pattern of oocyte production, regulative atresia, and maturation of remanent oocytes, which are spawned in a single or several (few) batches.
The presence of oocytes at different stages of maturation and, particularly, the occurrence of a distinct group of oocytes in an advanced maturation stage were considered to be evidence of multiple spawning in G. pacifica and in G. macrotyla (Bello 2006; Guerra et al. 2012). However, the term "multiple spawning" should only be applied to species with group-synchronous oocyte production, monocyclic spawning pattern, and somatic growth between separate egg batches, such as the lesser Pacific strip octopus Octopus chierchiae from low inter-tidal tropical areas (Rodaniche 1984; Rocha et al. 2001). Although this reproductive strategy would be the most suitable for deep cold-water octopods, the existence of somatic growth between spawning events in Graneledone species is controversial. Graneledone females have to brood an egg mass and protect it against predators, as recorded by submarines (Voight and Grehan 2000) and ROVs (Drazen et al. 2003). In this situation, feeding would be fairly casual. It is hard to believe that after a few months of brooding under a condition of half starvation, a female would be able to lay a new egg mass in a different place, and even to grow between these spawning events (Laptikhovsky pers. comm.). Thus, G. macrotyla should not be considered a multiple spawner. On the other hand, since growth does not take place between egg batches, G. macrotyla should neither be considered a continuous spawner.

The reproductive traits and the characteristics of the developing oocytes found in the five G. macrotyla females (Tables 1 and 2) suggest that the species' maximum observed potential fecundity (PF) or total number of all oocytes or initial oocyte reserve (Laptikhovsky 2001) ranged between 250 and 300 eggs, similar to that of G. pacifica (Bello 2006). Two octopod species from the Bering Sea caught at depths of 200-600 m, Bathypolypus salebrosus and Benthoctopus sp. aff. sibiricus, showed maximum PF of 204 and 195, respectively (Laptikhovsky 1999). PF in Benthoctopus eureka, an octopod of cold waters from 80 to $2500 \mathrm{~m}$ depth around the Falkland (Malvinas) islands, ranged from 250 to 535 (Laptikhovsky 2001), which are scenarios comparable to that of G. macrotyla.

\section{Atresia}

Atretic oocytes were found along with those in stages S1 and S4 (Table 2). Atresia has been observed in many marine organisms, including cephalopods (e.g., Guraya 1986; Melo and Sauer 1998; Boyle and Chevis 1991; Laptikhovsky 1999, 2001; Laptikhovsky and Arkipkin 2001). In the case of G. pacifica, a set of oocytes develop to maturity and are spawned, whereas the remaining oocytes fail to grow beyond about $3 \mathrm{~mm}$ length and degenerate (Bello 2006). The percentage of atretic oocytes found in 
the squid Doryteuthis gahi inhabiting the shelf and continental slope was about $1 \%$ of the total number of oocytes (Laptikhovsky and Arkipkin 2001). However, atresia can affect a much higher percentage of initial oocytes; for instance, in the Antarctic Eledoninae, Pareledone charcoti, $P$. polymorpha and $P$. turqueti 42, 29, and $54 \%$, respectively, of the initial number of oocytes were resorbed (Kuehl 1988). Moreover, residual degenerated oocytes amounted to 60-80\% in Bathypolypus salebrosus, and 50-60\% in Benthoctopus sp. aff. sibiricus from Artic waters (Laptikhovsky 1999). Thus, atresia percentages found in G. macrotyla coincide with those observed in other cold-water octopods.

Several factors have been advanced as possible reasons for oocyte atresia, mainly in fish, as summarized by Melo and Sauer (1998). These include overcrowding, environmental conditions such as temperature and day length, food restriction, and body size. The possible explanation for atresia in L. vulgaris reynaudii was that atresia plays a role in the removal of surplus oocytes, given that oogenesis is energetically costly, particularly in short-living species (Melo and Sauer 1998). The scanty number of female G. macrotyla examined, as well as the lack of knowledge on many aspects of the species' life cycle, does not allow us to formulate any well-founded hypothesis. However, given the stable oceanographic conditions of the bottom deep waters along most of the Argentine continental slope, the most plausible explanation for atresia in G. macrotyla might be food restriction. Atlantic cod females initiate gonad development up to seven months prior to spawning (Burton et al. 1997). During that period, impaired or nonimproving feeding conditions may render reproduction less attractive; accordingly, energy temporarily invested in gonads can later be reabsorbed through atresia (Kjesbu et al. 1991).

Although no POFs were observed in female G. macrotyla, the existence of POFs in the ovaries examined cannot be excluded. This is because of the inadequate process of conservation of the specimens, the difficulty of obtaining good histological sections from a material unsuitably preserved, and finally, because POFs would be attached forming a bunch inside the ovary together with the other types of oocytes, making their identification difficult.

Degeneration of oocytes within the ovaries could be an artifact produced by cell damage due to preservation, since the animals were frozen during 12 and 5 months on the ATLANTIS 2009 and 2010 cruises, respectively. It has been observed that conservation hampers the identification of yolk granules with visible or fluorescent light (SaboridoRey 2012). Furthermore, the high salt content of marine invertebrate cells leads to extensive cellular damage during freezing (Dixon et al. 2002), and freezing induced artificial cleavage of apoptosis-related proteins in human bone marrow (Schmidt-Mende et al. 2000). Nevertheless, if the preservation was the reason, why do specimens caught at the same time, in the same place and preserved in the same conditions (MDMG 68A2011 and MDMG68B2011) show such different oocyte stages (S3 and S4, see Table 2) within their ovaries? Although similar levels of atresia were observed in ovaries of Muusoctopus sp that were fixed in formalin straight after capture (Laptikhovsky pers. comm.), further analyses using fresh material are needed to elucidate whether the scenario shown in some G. macrotyla females is a matter of apoptosis or atresia.

Acknowledgments The authors wish to express their great acknowledgment to the members of the research team who participated in the cruise and contributed to the collection of the samples. The authors also thank the ship's crew for their professionalism and the courtesy to the scientific group during the research cruise. We also wish to express our gratitude to Drs. Vladimir V. Laptikhovsky, Ángel F. González, and Santiago Pascual for their valuable comments, to Mr. José Manuel Antonio and Mrs. María T. Fernández for technical assistance, to Mr. Manuel Enrique García Blanco (Garci) for images, and to Mr. Ian Emmet for improving the English.

\section{References}

Barrat IM, Johnson MP, Collins MA, Allcock AL (2008) Female reproductive biology of two sympatric incirrate octopod species, Adelieledone polymorpha (Robson, 1930) and Pareledone turqueti (Joubin, 1905) (Cephalopoda: Octopodidae) from South Georgia. Polar Biol 31:583-594

Bello G (2006) Signs of multiple spawning in Graneledone pacifica (Cephalopoda: Octopodidae). J Mar Biol Assoc UK 86:11831186

Boyle PR, Chevis D (1991) Changes in follicle cell epithelium nuclei at the onset of vitellogenesis in the octopus Eledone cirrhosa. Bull Mar Sci 49:372-378

Burton MPM, Penney RM, Biddiscombe S (1997) Time course of gametogenesis in Northwest Atlantic cod (Gadus morhua). Can J Fish Aqua Sci 54:122-131

Dixon D, Priski RAM, Dixon LRJ, Jha AN (2002) Marine invertebrate eco-genotoxicology: a methodological overview. Mutagenesis 17:495-507

Drazen JC, Goffredi SAK, Schilling B, Stakes D (2003) Aggregations of egg-brooding deep-sea fish and cephalopods on the Gorda Escarpement: a reproductive hot spot. Biol Bull 205:1-7

Franzén Ä (1955) Comparative morphological investigations into the spermiogenesis among Mollusca. Zool Bid Upps 30:399-456

Gabe N (1968) Techniques histologiques. Masson et Cie, Paris

Guerra A, Portela JM, del Río JL (2011) Cephalopods caught in the outer Patagonian shelf and its upper and medium slope in relation with the main oceanographic features. Fish Res 109: 179-186

Guerra A, Roura A, Sieiro MP, Portela JM, del Río JL (2012) New insights on the morphology, reproduction and distribution of the large-tuberculate octopus Graneledone macrotyla from the Patagonian slope. Sci Mar 76:3129-3328

Guraya SS (1986) The cell and molecular biology of fish oogenesis. In: Sauer HW (ed) Monographs in development, vol 18. Karger, New York, pp 163-194

Healy JM (1988) Sperm morphology and its systematic importance in Gastropoda. Malacol Rev 4:251-266 
Kjesbu OS, Klungsøyr J, Kryvi H, Witthames PR, Walker MG (1991) Fecundity, atresia, and egg size of captive Atlantic cod (Gadus morhua) in relation to proximate body composition. Can J Fish Aqua Sci 48:2333-2343

Kuehl S (1988) A contribution of the reproductive biology and geographical distribution of Antarctic Octopodidae (Cephalopoda). Malacologia 29:89-100

Laptikhovsky VV (1999) Fecundity and reproductive strategy of three species of octopods from the Northwest Bering Sea. Russ J Mar Biol 25:342-346

Laptikhovsky VV (2001) Fecundity, egg masses and hatchlings of Benthoctopus spp (Octopodidae) in Falkland waters. J Mar Biol Assoc UK 81:267-270

Laptikhovsky VV, Arkipkin AI (2001) Oogenesis and gonad development in the cold water loliginid squid Loligo gahi (Cephalopoda: Myopsida) on the Falkland shelf. J Mollus Stud 67: 475-482

Laptikhovsky VV, Arkipkin AI, Hoving HJT (2007) Reproductive biology of two species of deep-sea squid. Mar Biol 152:981-990

Longo FJ, Anderson A (1970) Structural and cytochemical features of the sperm of the cephalopod Octopus bimaculatus. J Ultrastruct Res 32:94-106

Mangold K (1989) Organes génitaux-Reproduction, croissance et durée de vie. In: Mangold K (ed) Céphalopodes. Traité de Zoologie, vol 5(4). Masson, Paris, pp 459-552

Melo YC, Sauer WHH (1998) Ovarian atresia in cephalopods. South Afr J Mar Sci 20:143-151

Perez JAA, Haimovici M, Cousin JCB (1990) Sperm storage mechanism and fertilization in females of two South American eledonids (Cephalopoda: Octopoda). Malacologia 32:147-154

Portela JM, Pierce GJ, del Río JL, Sacau M, Patrocinio T, Vilela R (2010) Preliminary description of the overlap between squid fisheries and VMEs on the high seas of the Patagonian Shelf. Fish Res 106:229-238

Rideout RM, Tomkiewicz J (2011) Skipped spawning in fishes: more common that you might think. Mar Coast Fish 3:176-189

Rocha F, Guerra A, González AF (2001) A review of the reproductive strategies in cephalopods. Biol Rev 76:291-304
Rodaniche A (1984) Itreroparity in the lesser Pacific octopus, Octopus chierchiae (Jatta, 1889). Bull Mar Sci 35:99-104

Roura A, Guerra A, González AF, Pascual S (2009) Sperm ultrastructural features of the bathyal octopod Graneledone gonzalezi. Vie et Milieu 59:301-305

Roura A, Guerra A, González AF, Pascual S (2010) Sperm ultrastructure in Bathypolypus bairdii and B. sponsalis (Cephalopoda: Octopoda). J Morphol 271:143-151

Saborido-Rey F (2012) Ecología de la reproducción y potencial reproductivo en las poblaciones de peces marinos. Instituto de Investigaciones Marinas (CSIC)-Universidad de Vigo, Curso doctorado, $71 \mathrm{pp}$

Saborido-Rey F, Domínguez-Petit R, Alonso-Fernández A (2007) A quick method for an easy identification of ovarian structures: the use of autofluorescence. In: NAFO/PICES/ICES symposium, reproductive and recruitment processes of exploited marine fish stocks, Octubre 2007, Lisboa, p 2.9

Sauer WHH, Mccarthy C, Smale MJ, Koorts AS (1993) An investigation of the egg distribution of the chokka squid, Loligo vulgaris reynaudii, in Krom Bay, South Africa. Bull Mar Sci 53:1066-1077

Schmidt-Mende J, Hellström-Lindberg E, Joseph B, Zhivotovsky B (2000) Freezing induces artificial cleavage of apoptosis-related proteins in human bone marrow cells. J Immun Meth 245:91-94

Selmi MG (1996) Spermatozoa of two Eledone species (Cephalopoda, Octopoda). Tissue Cell 28:613-620

Voight JR (2001) Morphological deformation in preserved specimens of the deep-sea octopus Graneledone. J Mollus Stud 67:95-102

Voight JR, Drazen JC (2004) Hatchling of the deep-sea octopus Graneledone boreopacifica are the largest and most advanced known. J Moll Stud 70:406-408

Voight JR, Grehan AJ (2000) Egg brooding by deep-sea octopuses in the North-Pacific Ocean. Biol Bull 198:94-100

Voss GL (1976) Two new species of octopods of the genus Graneledone (Mollusca: Cephalopoda) from the Southern Ocean. Proc Biol Soc Wash 88:447-458 